\title{
Allogeneic Bone Grafting Materials - Update of the Current Scientific Status
}

\author{
R. Schnettler ${ }^{1}$, J. Franke ${ }^{2}$, D. Rimashevskiy ${ }^{3}$, N. Zagorodniy ${ }^{3}$, Batpenov N. ${ }^{4}$, \\ R.E. Unger ${ }^{5}$, S. Wenisch ${ }^{6}$, M. Barbeck ${ }^{7,8}$ \\ ${ }^{1}$ University Medical Center, Justus Liebig University of Giessen, Giessen, Germany \\ ${ }^{2}$ Elbe Klinikum, Stade, Germany \\ ${ }^{3}$ Peoples> Friendship University of Russia, Moscow, Russian Federation \\ ${ }^{4}$ Scientific Research Institute of Traumatology and Orthopedics, Astana, Kazakhstan \\ ${ }^{5}$ Institute of Pathology, Johannes Gutenberg University, Mainz, Germany \\ ${ }^{6}$ Institute of Veterinary Anatomy, Histology and Embryology, \\ Justus Liebig University of Giessen, Giessen, Germany \\ ${ }^{7}$ Berlin-Brandenburg Center for Regenerative Therapies (BCRT), Charité-Universitätsmedizin Berlin, \\ Berlin, Germany \\ ${ }^{8}$ Botiss Biomaterials, Berlin, Germany
}

\begin{abstract}
Worldwide population aging and associated with it epidemics of osteoporosis, widespread of bone and joint reconstructive surgery and first of all joint replacement lead to explosive growth of interest in bone grafting.

Although autografts are still the golden standard in bone regeneration, allogeneic bone substitutes have reached a state that allows for their application with satisfying clinical results. However, it has repeatedly been supposed that the different allogeneic materials underwent different purification processes, which modifies bone regeneration properties of these materials and also for different safety conditions. In the present publication, the treatment of the precursor tissue, the safety conditions, and the regenerative possibilities of C+TBA bone blocks based in preclinical and clinical data are described. Thus, it is described how the risks of infections and also immunological reactions becomes completely eliminated, while the special purification process allows for preservation of the native structure of the bone block. Both the in vitro studies and the clinical trials including histological follow-ups showed the optimal regeneration properties of these bone blocks. It has been shown that the allogeneic bone grafts have been integrated without causing inflammatory anomalies at the implantation site. Altogether, the allogeneic bone substitute material serves as an excellent basis for the formation of new bone. Finally, the combination of the allogeneic C+TBA bone blocks with different antibiotics is described. Interestingly, it is possible to combine the allogeneic bone substitute ether with antibiotics in the sense of prophylaxis and/or with bone marrow aspirate in order to accelerate bone remodeling.
\end{abstract}

Keywords: allogeneic bone substitute, bone grafting, bone tissue regeneration.

[C] Schnettler R., Franke J. Rimashevskiy D., Zagorodniy N., Batpenov N., Unger R.E., Wenisch S., Barbeck M. Allogeneic Bone Grafting Materials - Update of the Current Scientific Status. Травматология и ортопедия России. 2017;23(4): 92-100. DOI: 10.21823/2311-2905-2017-23-4-92-100.

Cite as: Шнеттлер Р., Франке И., Римашевский Д.В., Загородний Н.В., Батпенов Н.Д., Унгер Р.Е., Вениш С., Барбек М. [Аллогенные костнопластические материалы: современное состояние проблемы]. Travmatologiya i ortopediya Rossii [Traumatology and Orthopedics of Russia]. 2017;23(4):92-100. (in Russian). DOI: 10.21823/2311-2905-2017-23-4-92-100.

$\triangle$ Reinhard Schnettler. Klinikstrasse, 29, D-35392 Giessen, Germany; e-mail: Reinhard.Schnettler@chiru.med.uni-giessen.de

Рукопись поступила/Received: 21.10.2017. Принята в печать/Accepted for publication: 15.11.2017. 


\title{
Аллогенные костнопластические материалы: современное состояние проблемы
}

\author{
Р. Шнеттлер ${ }^{1}$, И. Франке ${ }^{2}$, Д.В. Римашевский ${ }^{3}$, Н.В. Загородний ${ }^{3}$, Н.Д. Батпенов ${ }^{4}$, \\ P.Е. Унгер ${ }^{5}$, С. Вениш ${ }^{6}$, М. Барбек ${ }^{7,8}$ \\ ${ }^{1}$ Университетский медицинский иентр Гиссена, Гиссенский университет Ю. фон Либиха, \\ Гиссен, Германия \\ ${ }^{2}$ Эльбе Клиника неотложной хирургии и ортопедии, Штаде, Германия \\ ${ }^{3}$ Российский университет дружбы народов, Москва, Россия \\ ${ }^{4}$ Научно-исследовательский институт травматологии и ортопедии, Астана, Республика Казахстан \\ ${ }^{5}$ Институт патологии, Университет Джоанеса Гутенберга, Майни, Германия \\ ${ }^{6}$ Институт ветеринарной анатомии, гистологии и эмбриологии Гиссенского университета Ю. фон Либиха, \\ Гиссен, Германия \\ ${ }^{7}$ Институт Юлиуса Вульфа и Центр скелетно-мышечной хирургии Шарите - Медицинский университет Берлина \\ ${ }^{8}$ Ботис Биоматериалс, Берлин, Германия
}

\section{Реферат}

Старение населения планеты и ассоциированная с ним эпидемия остеопороза, а также широкое распространение реконструктивных операций на костях и суставах, в первую очередь эндопротезирования, привели к взрывному росту интереса к костной пластике.

Несмотря на то, что аутотрансплантаты по-прежнему остаются «золотым стандартом» при замещении костных дефектов, аллогенные костнозамещающие материалы достигли такого уровня качества, который позволяет с успехом применять их в клинической практике. Неоднократно высказывались предположения, что разные способы обработки различных типов аллогенных материалов по-разному меняют их регенеративные свойства и характеристики безопасности.

В статье описана технология обработки исходного материала, перечислены требования к безопасности аллокости, регенеративные возможности костных блоков С+ТВА. Приводятся подтверждающие данные доклинических и клинических исследований. Технология С+ТВА позволяет практически полностью исключить риск развития иммунологических реакций и передачи инфекции, а специальные этапы обработки позволяют сохранить естественную структуру костного блока. Клинические и in vitro исследования с гистологическим контролем на разных этапах показали оптимальные регенеративные характеристики таких костных блоков. Аллогенная кость интегрировалась, не вызывая локальных воспалительных реакций в месте трансплантации. В целом аллогенные костнозамещающие материалы являются отличной основой для формирования новой кости. В статье описаны комбинации аллогенных костных блоков С+ТВА с различными антибиотиками с целью профилактики инфекции и/или с пунктатом костного мозга для стимуляции перестройки кости.

Ключевые слова: аллогенные костнопластические материалы, костная пластика, регенерация костной ткани.

DOI: 10.21823/2311-2905-2017-23-4-92-100

Конфликт интересов: не заявлен.

Источник финансирования: исследование проведено без спонсорской поддержки.

\section{Introduction}

Autologous bone grafting is considered to be the gold standard in case of bone tissue regeneration due to its osteogenic, osteoinductive and osteoconductive potential [1, 2]. However, the application of autologous bone can cause complications as a further operative intervention at another localization as the intended implant site has to be performed [3].

In this context, the harvest of autografts is often associated with side effects and possible infections [3, 4]. Additionally, the amount of obtainable autologous bone tissue is often too small to fill the defect or implantation site [4]. As a substitute for autologous bone transplants or for its volume increase the clinician has different alternatives as various bone grafting materi- als are available, which are based on allogeneic, xenogeneic or synthetic origin $[1,5]$. Although all material classes support the bone tissue regeneration process primarily via osteoconduction, the highest regenerative capacity is attributed to allogeneic materials. This has been assigned to the fact that the human donor tissue is suggested to have the highest similarity to the target tissue of the recipient organism $[2,6]$.

Even in case of naturally derived biomaterials such as allogeneic bone substitutes it is indispensable that the donor tissue becomes purified from potential immunogenic components such as the bone tissue related cells to prevent graft rejections and also possible disease transmissions [7]. In this context, different physical and chemical processes are applied for puri- 
fication of the different commercially available allogeneic bone substitutes.

Based on its purification processes, allografts can be roughly divided into physically and physico-chemically processed materials [8]. The physically processed allografts include globally widespread materials such as fresh-frozen bone and cryopreserved bone, in which the cellular constituents are completely preserved $[9,10]$. In this case, the obtained transplants become only frozen $\left(\right.$ ca. $-20^{\circ} \mathrm{C}$ ) and partially irradiated (freshfrozen bone) or treated with cryoprotective agents such as dimethyl sulfoxide (DMSO) or glycerol and stored at about $-196^{\circ} \mathrm{C}$ (cryopreserved bone), respectively. In case of these both bone substitute materials, viable cells could be detected, which even is an explicit target in the case of the cryopreservation procedure ${ }^{1}$ [9].

However, most allogeneic bone implants undergo chemical decellularization processes including different purification steps and chemicals (Table).

The final drying process, which ensures the stable storage of the bone blocks at room temperature, is carried out either by evaporation of acetone (Puros Allograft, Tutoplast ${ }^{\circledR}$ Spongiosa Block), which is similar to the literature referenced solvent-dehydrated bone allografts (SDBA), or by freeze-drying (all other providers), which is often referred to as freeze-dried bone allografts (FDBA) [14, 15]. In total, mineralized bone allograft (MBA) is used as collective term for these materials [16].

Altogether, the aim of these purification processes is to generate a bone grafting material, which primarily serves as osteoconductive scaffold and allows optimal bone tissue healing with optimal physicochemical properties without containing immunogenic ingredients. Finally, it is essential to assess allogeneic bone grafting materials after their complete processing in order to correctly evaluate their properties and the associated safety.

\section{Treatment of bone blocks}

The treatment of the original tissue from extraction to final preparation should be described by using the example of an allograft (allogenic bone block, Cells + Tissuebank Austria (C+TBA), Austria), which is processed by the so-called Allotec ${ }^{\circledR}$-process under special consideration of certain safety aspects. Prior to the wet-chemical treatment, a multi-stage selection process becomes applied to guarantee ideal material quality and highest safety standards. This process starts with the evaluation of the femoral heads by an experienced orthopedic surgeon who performs an initial clinical evaluation on basis of computertomographic (CT) data prior to extraction. Thereby, the bone quality is evaluated in order to detect any potential compromising properties such as bone lesions and, thus, to prevent bone donation as early as possible ${ }^{4}$. Furthermore, a detailed anamnesis and serological tests of the donors blood including HIV $1 / 2, \mathrm{HBV}, \mathrm{HCV}$ and syphilis infections is performed to significantly reduce the risk of infection transmission prior to removal ${ }^{4}$. Only after a sufficient approval of all these safety parameters, the donor tissue is accepted for removal and subsequent processing.

Afterwards, the femoral heads become physicochemically processed to obtain sterile biomaterials in the Good Manufacturing Practice (GMP)-compliant cleanrooms of the C+TBA. Initially, tissue residues are manually removed and the bone tissue is divided into particles, blocks and rings. Thereafter, the raw bone material is transferred to an ultrasonic bath to remove tissue or cell components in order to prepare the donor tissue for the subsequent application of chemicals and, thus, for subsequent decellularization (See таble). This process step includes alternating rinsing with ethanol and diethyl ether as well as oxidative treatment with hydrogen peroxide. Ethanol and die-

List of chemicals applied for the decellularization of different commercially available

Table allogeneic bone blocks

\begin{tabular}{l|l}
\hline \multicolumn{1}{c|}{ Allograft } & \multicolumn{1}{c}{ Applied Chemicals } \\
\hline Puros Allograft, Tutoplast ${ }^{\circledR}$ Spongiosablock [11] & $\begin{array}{l}\text { Hydrogen peroxide, NaOH, Ethanol, Acetone } \\
\text { Peracetic acid - ethanol }\end{array}$ \\
C+TBG-bone blocks [12] & $\begin{array}{l}\text { Diethyl ether, ethanol, hydrogen peroxide } \\
\text { Ethanol, Chloroform, Hydrogen peroxide, Sodium } \\
\text { TBF-bone blocks }\end{array}$ \\
& hypochlorite
\end{tabular}

\footnotetext{
${ }^{1}$ Sancho-Navarro R et al. Cell Viability in a Cryopreserved Human Cancellous Allograft. Revista espanola de cirugia ortopedica y traumatologia (english edition). ELSEVIER, AMSTERDAM, NL, vol. 52, no. 1, 1 January 2008 (2008-01-01), pages 27-31.

${ }^{2}$ Der ALLOTEC ${ }^{\circledR}$ prozess. Abailable at: https://www.ctba.at/de/Transplantate/C-TBA-Prozess.

${ }^{3}$ Treatment Process. Available at: http://www.tbf-lab.com/dent/en/phoenix-process/treatment-process.html.

${ }^{4}$ Cells + Tissuebank Austria, Gebrauchs- und Fachinformation. Available at: http://ctba.at/downloads/broschur_ansicht.pdf.
} 
thyl ether cause the denaturation of non-collagenous proteins as well as the elimination of remaining bacteria and a virus inactivation while residual genetic material fragments are destroyed by the application of hydrogen peroxide [17-19]. In this way, the risks of infections and also immunological reactions are completely eliminated. To remove liquid residues the donor tissue is then subjected to freeze drying, which allows for preservation of the native structure of the bone block (Fig. 1). Then, the final sterilization of the bone material is processed by means of low-dose gamma irradiation in order to additionally exclude possible contamination by microorganisms ${ }^{5}[17-20]$.

\section{Safety aspects of allogeneic bone grafting materials}

In the past, reports of infection transmissions and immunological reactions as a result of the application of bone grafts have compromised the safety of these materials [21]. While these concerns might be justified for unprocessed or only physically treated allogeneic bone grafting materials, physico-chemically processed materials only maintain a hypothetical residual risk $[22,23]$. Thus, the transmission of infectious diseases has only been reported for allografts, which were not physico-chemically or not correctly treated, respectively $[24,25]$. However, since the introduction of the so-called Nucleic Acid Test (NAT), a highly sensitive and specific test for the detection of even the smallest amounts of genetic material of pathogens, in 2004, no disease transmission was reported by the transplantation of human bone [22].
Infrequent reports, which have reported an allosensitization of recipients of human bone grafts, have shown to be mainly related to application of fresh or freshly frozen bone [26-28]. Only G.E. Friedlaender et $a l$. have reported an allo-sensitization by the transplantation of freeze-dried musculoskeletal allografts in orthopedic application [29]. However, the latter did not result in any clinical effects. In addition, it should be mentioned that the processing and the quality standards of the materials used in this study did not match the processing of other allografts. Furthermore, no donor-specific antibodies could up to now be detected in recipients of physico-chemically processed allogeneic bone blocks. In addition, it was shown that even the mismatch of the so-called human leukocyte antigens (HLA), which represents a protein family that allows the immune system to distinguish the body's own proteins from exogenous proteins, has no influence on the ingrowth of allogeneic bone grafts [30-32].

On basis of the above described purification process of C+TBA allografts, the risk of infection transmission or an allo-sensitization caused by the chemically processed and freeze-dried allografts is no more present. Although single cell components could be detected within the bone matrix, there is no evidence of any clinical effects by these results [22, 31-35]. Thus, over the past twenty years, there was no reported case of this bone grafting material, which caused the transmission of an infection, nor a single case, which documented a health problem of a recipient of decellularized allografts [33].
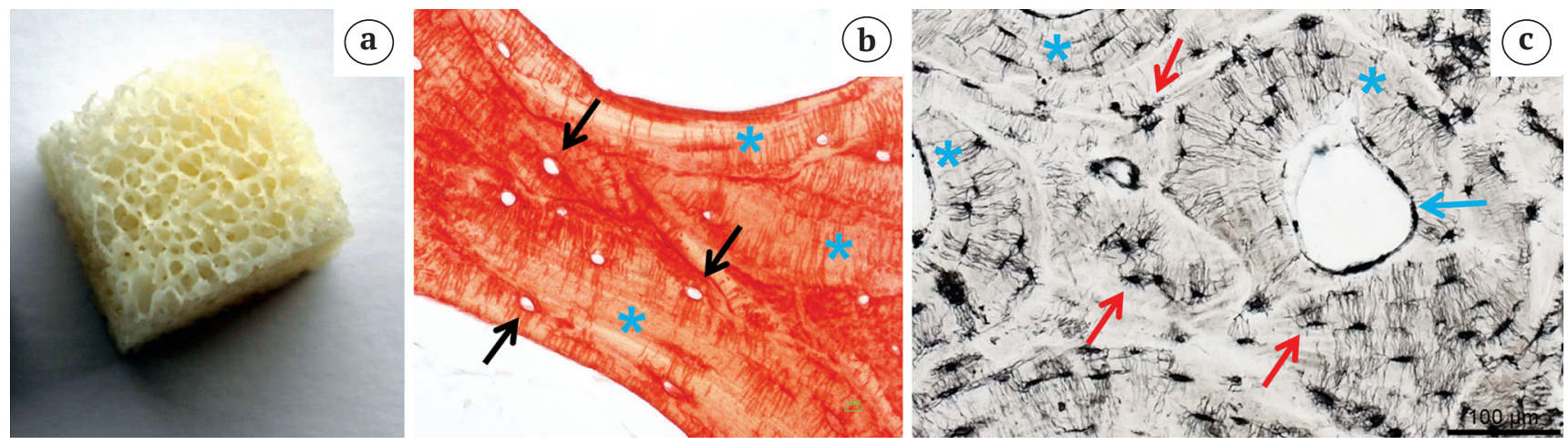

Fig. 1. Image of a C+TBA bone block with a clearly visible trabecular structure (a). Histological image of the bone block showing its clearly visible lamellar structure (asterisks) and the empty matrix lacunae (arrows) (Sirius-staining, $400 \times$ magnification) (b). Electron microscopical image showing the basic structure of the C+TBA bone block (c). The preservation of the lamellar ultrastructure (asterisks) and the complete purification of both the Haversian channels (blue arrow) and the osteocyte lacunae (red arrows) is clearly visible (black coloring = processing-related coloring = empty areas; $1250 \times$ magnification)

${ }^{5}$ Cells + Tissuebank Austria, Gebrauchs- und Fachinformation. Available at: http://ctba.at/downloads/broschur_ansicht.pdf. 


\section{Bone tissue regeneration using allogeneic bone grafting materials}

Bone is the best substitute for bone. Thus, it makes sense to fill the defects up with allogeneic bone especially based on their physico-chemical similarity to that of the bone matrix of the recipients bone tissue in all cases of defect fractures with critical size bone defects. Allogeneic bone substitute materials are available in many different forms, i.e., granules, blocks, wedges etc. in order to (Fig. 2).

In this context, in vitro studies have demonstrated the excellent biocompatibility and bone compatibility of allogeneic C+TBA bone blocks as a substrate for osteoblastic growth [unpublished data by Unger et al.] (Fig. 3).

Moreover, clinical trials including histological follow-ups allowed to prove the optimal regeneration properties of these bone blocks (Fig. 4-8). In this context, it has been shown that the allogeneic bone grafts have been integrated without causing inflammatory anomalies at the implantation site (Fig. 8). Moreover, the allogeneic bone substitute material serves as an excellent basis for the formation of new bone (Fig. $8 \mathrm{a}$ and $\mathrm{b}$ ).
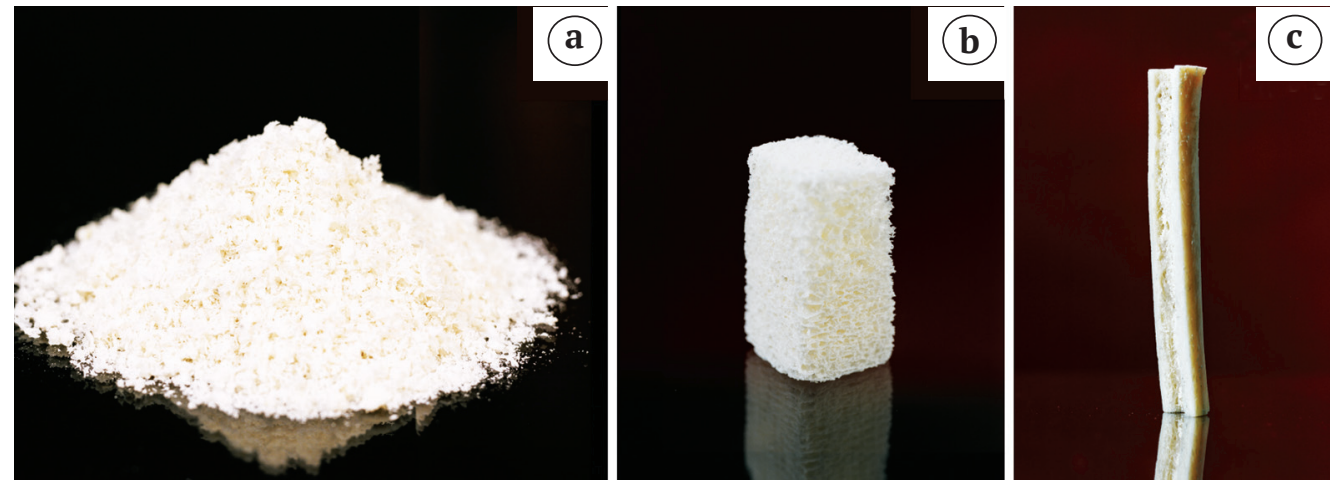

Fig. 2. The allogeneic bone substitute material is available in many different shapes, i.e., as granules (a), blocks (b) or in diaphysial shape (c)
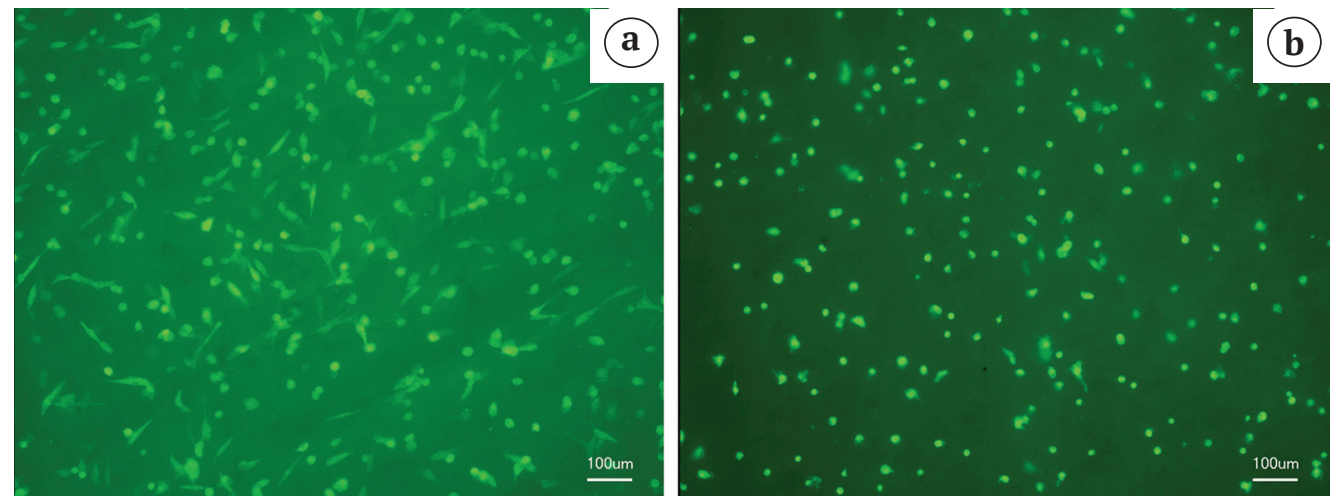

Fig. 3. Cellular growth behavior of osteoblastic MG-63 cells (a) and primary human osteoblasts (b) onto the allogeneic bone grafting material (Calcein-staining, $100 \times$ magnification)
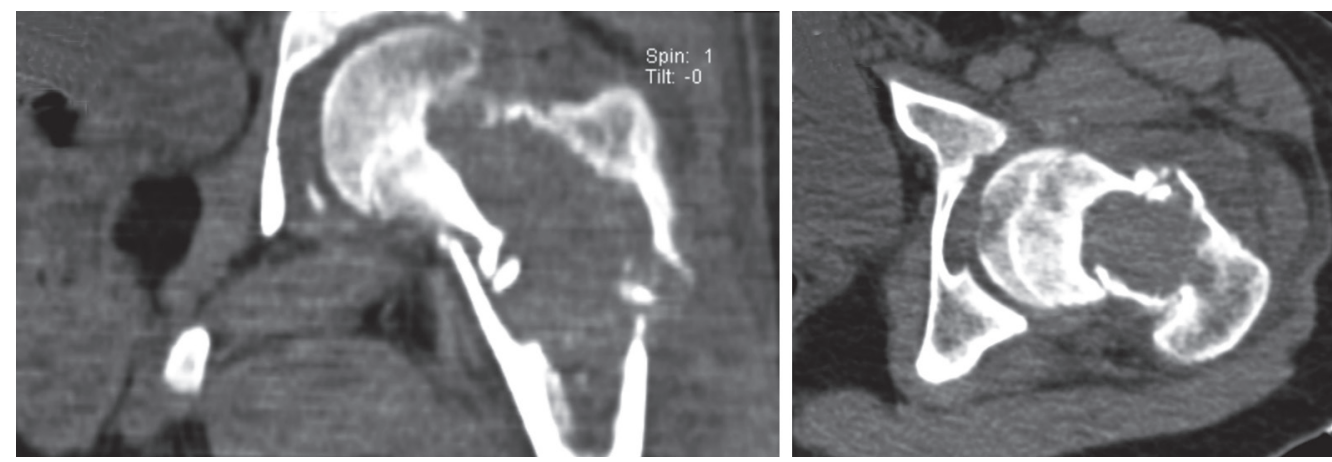

Fig. 4. Pathological peritrochanteric fracture juvenile cyst of a 12-year boy 

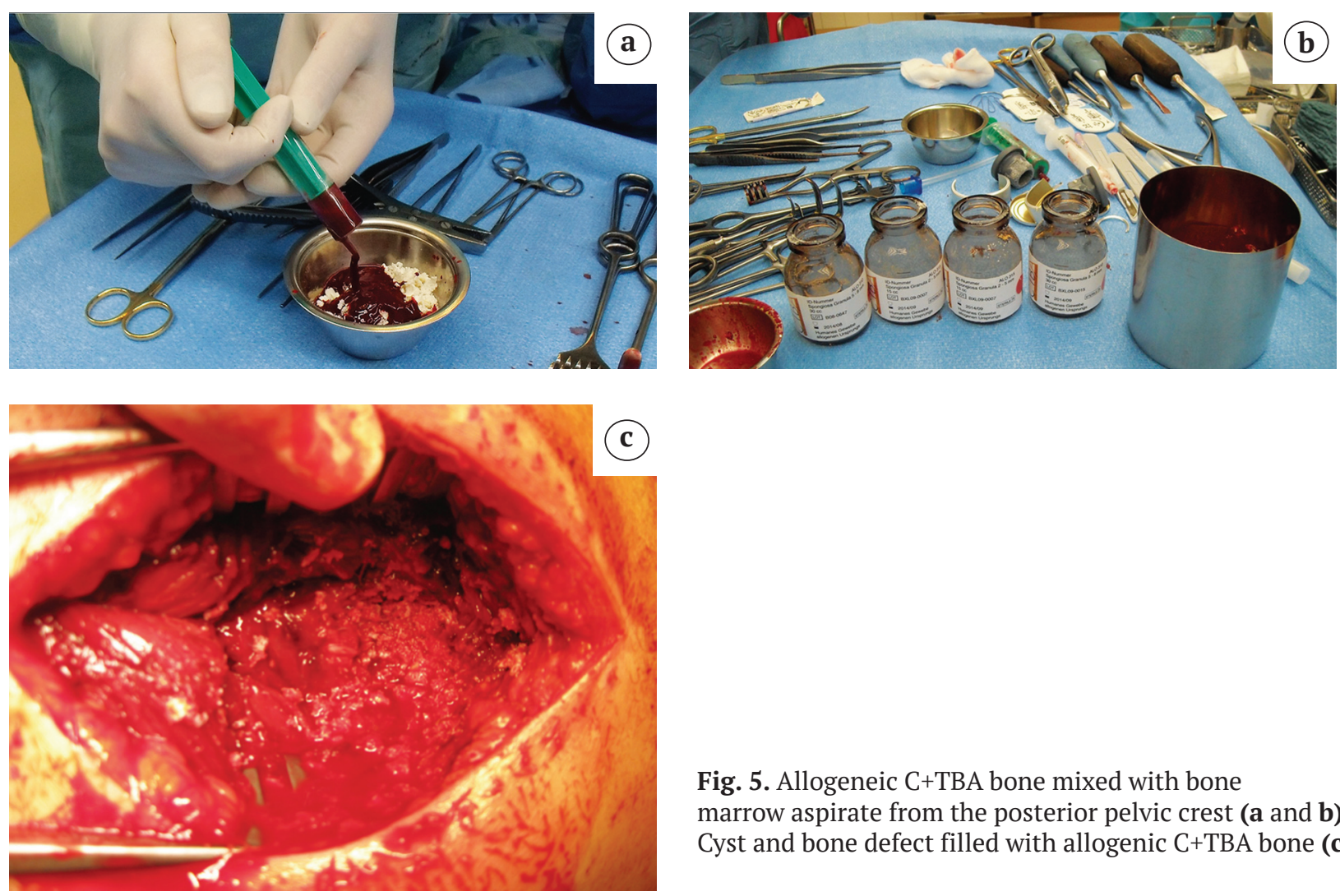

Fig. 5. Allogeneic C+TBA bone mixed with bone marrow aspirate from the posterior pelvic crest (a and $\mathbf{b}$ ). Cyst and bone defect filled with allogenic C+TBA bone (c)
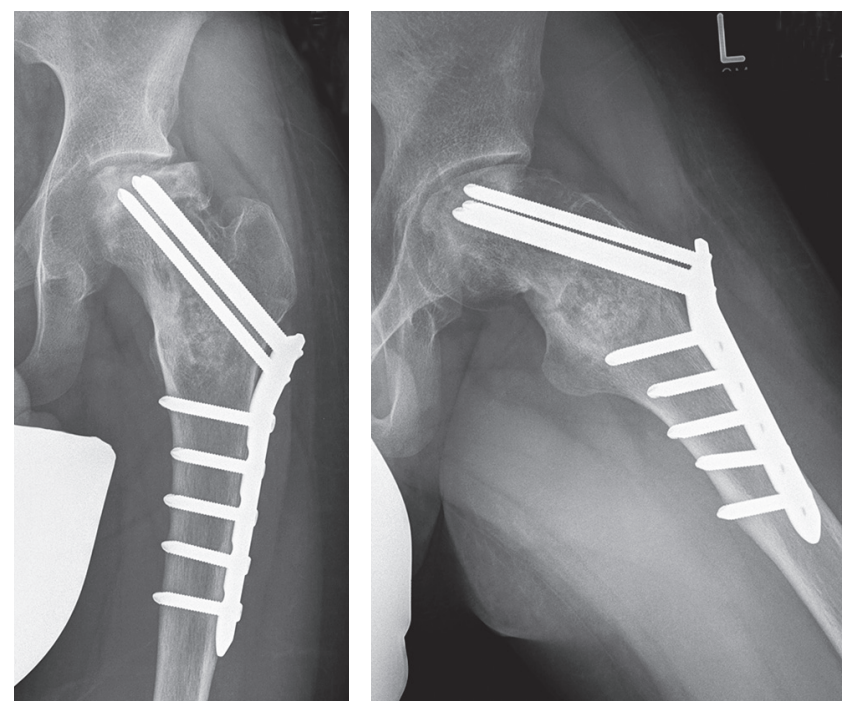

Fig. 6. Stabilization of the defect side with a plate osteosynthesis
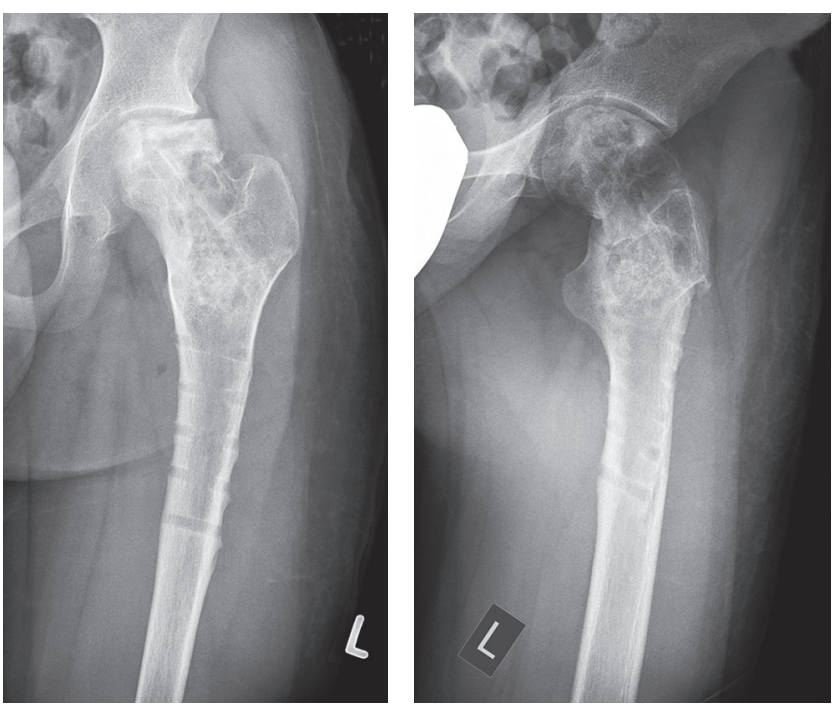

Fig. 7. Plate removal after 6 months after operation with good remodeling of the implanted allograft material (C+TBA) 

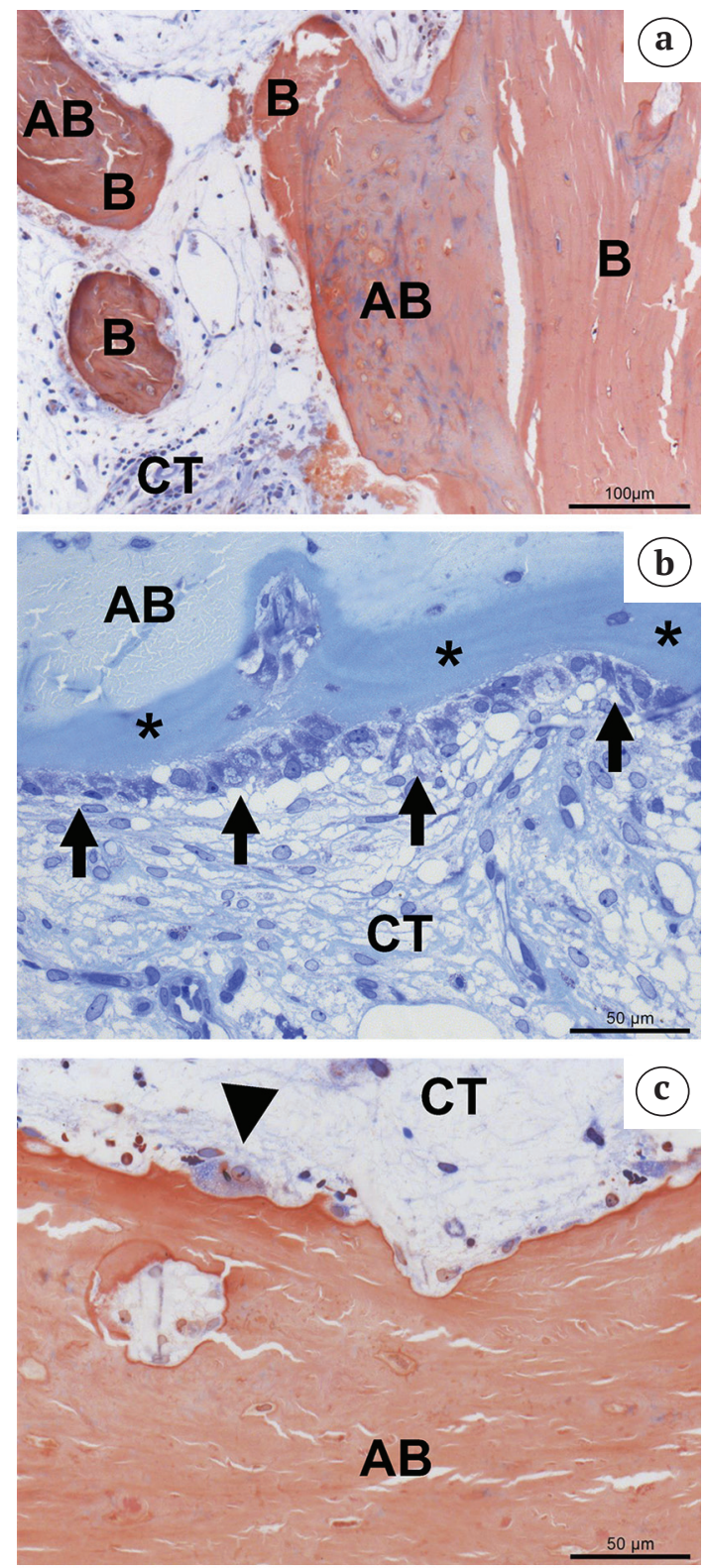

Fig. 8. Representative histological images showing bone regeneration after application of the $\mathrm{C}+\mathrm{TBA}$ bone block $(A B)$. Newly formed bone $(B)$ on the material surfaces $(\mathrm{AB}), \mathrm{CT}=$ connective tissue (HE-staining, $100 \times$ magnification) (a). Osteoblasts (arrows) and osteoid formation (asterisks) on the surface of a allogeneic $\mathrm{C}+\mathrm{TBA}$ bone block $(\mathrm{AB})$,

$\mathrm{CT}=$ connective tissue (Toluidine-staining, 400x magnification) (b). Degradation of the bony matrix of the C+TBA bone block (AB) by osteoclasts (arrowheads), $\mathrm{CT}=$ connective tissue (HE- staining, $400 \times$ magnification) (c)

\section{Infection treatment using a combination of allografts and antibiotics}

Postoperative infections after joint replacement with severe bone loss often requires bone reconstruction procedures. The management of infections of bone after joint replacement has always been difficult and is still a challenge for surgeons. In recent decades, the standard treatment for osteitis has been serial aggressive debridement followed by extensive lavage with 8-10 liters of pulsed saline. Long-term systemic antibiotics often combined with the combination of local antibiotics followed by reconstruction of skeletal defects is the modern way of treatment [36-38]. Nevertheless, the essential step in the treatment of bone infections is radical debridement with removal of dead bone and all foreign materials. Interestingly, it is possible to combine the allogeneic bone substitute ether with antibiotics in the sense of prophylaxis or with bone marrow aspirate in order to accelerate bone remodeling (See fig. 5).

Competing interests: the authors declare that they have no competing interests.

Funding: the authors have no support or funding to report.

\section{References}

1. Finkemeier C.G. Bone-grafting and bone-graft substitutes. J Bone Joint Surg Am. 2002;84-A(3):454-464.

2. Giannoudis P.V., Dinopoulos H., Tsiridis E. Bone substitutes: an update. Injury. 2005;36 Suppl 3:20-27.

3. Kurz L.T., Garfin S.R., Booth R.E. Jr. Harvesting autogenous iliac bone grafts: a review of complications and techniques. Spine (Phila $\mathrm{Pa}$ 1976). 1989;14(12):1324-1331.

4. Dimitriou R., Mataliotakis G.I., Angoules A.G., Kanakaris N.K., Giannoudis P.V. Complications following autologous bone graft harvesting from the iliac crest and using the RIA: a systematic review. Injury. 2011;42 Suppl 2:3-15. DOI: 10.1016/j.injury.2011.06.015.

5. Laurencin C., Khan Y., El-Amin S.F. Bone graft substitutes. Expert Rev Med Devices. 2006;3(1):49-57.

6. Schmitt C.M., Doering H., Schmidt T., Lutz R., Neukam F.W., Schlegel K.A. Histological results after maxillary sinus augmentation with Straumann ${ }^{\circledR}$ BoneCeramic, Bio-Oss ${ }^{\circledR}$, Puros ${ }^{\circledR}$, and autologous bone. A randomized controlled clinical trial. Clin Oral Implants Res. 2013;24(5):576-585. DOI: 10.1111/j.1600-0501.2012.02431.x.

7. Damien C.J., Parsons J.R. Bone graft and bone graft substitutes: a review of current technology and applications. J Appl Biomater. 1991;2(3):187-208.

8. Malinin T., Temple H.T. Comparison of frozen and freeze-dried particulate bone allografts. Cryobiology. 2007;55(2):167-170.DOI:10.1016/j.cryobiol.2007.05.007.

9. Simpson D., Kakarala G., Hampson K., Steele N., Ashton B. Viable cells survive in fresh frozen human bone allografts. Acta Orthop. 2007;78(1):26-30. DOI: 10.1080/17453670610013385.

10. Borghetti A., Novakovitch G., Louise F., Simeone D., Fourel J. Cryopreserved cancellous bone allograft in periodontal intraosseous defects. J Periodontol. 1993;64(2):128-132. DOI: 10.1902/jop.1993.64.2.128. 
11. Schoepf Ch. The Tutoplast ${ }^{\circledR}$ Process: a review of efficacy. Zimmer Dental. 2008;17:40-50.

12. Pruss A., Göbel U.B., Pauli G., Kao M., Seibold M., Mönig H.J., Hansen A., von Versen R. Peracetic acidethanol treatment of allogeneic avital bone tissue transplants--a reliable sterilization method. Ann Transplant. 2003;8(2):34-42.

13. Osbon D.B., Lilly G.E., Thompson C.W., Jost T. Bone grafts with surface decalcified allogeneic and particulate autologous bone: report of cases. J Oral Surg. 1977;35(4):276-284.

14. Lee D.W., Pi S.H., Lee S.K., Kim E.C. Comparative histomorphometric analysis of extraction sockets healing implanted with bovine xenografts, irradiated cancellous allografts, and solvent-dehydrated allografts in humans. Int J Oral Maxillofac Implants. 2009;24(4):609-615.

15. Mellonig J.T. Freeze-dried bone allografts in periodontal reconstructive surgery. Dent Clin North Am. 1991;35(3):505-520.

16. Beck T.M., Mealey B.L. Histologic analysis of healing after tooth extraction with ridge preservation using mineralized human bone allograft. I Periodontol. 2010;81(12):1765-1772. DOI: 10.1902/jop.2010.100286.

17. Kluger R., Bouhon W., Freudenberger H., Kröner A., Engel A., Hoffmann O. Removal of the surface layers of human cortical bone allografts restores in vitro osteoclast function reduced by processing and frozen storage. Bone. 2003;32(3):291-296.

18. Asselmeier M.A., Caspari R.B., Bottenfield S. A review of allograft processing and sterilization techniques and their role in transmission of the human immunodeficiency virus. Am J Sports Med. 1993;21(2):170-175. DOI: $10.1177 / 036354659302100202$.

19. Linley E., Denyer S.P., McDonnell G., Simons C., Maillard J.Y. Use of hydrogen peroxide as a biocide: new consideration of its mechanisms of biocidal action. J Antimicrob Chemother. 2012;67(7):1589-1596. DOI: $10.1093 / \mathrm{jac} / \mathrm{dks} 129$.

20. Singh R., Singh D., Singh A. Radiation sterilization of tissue allografts: A review. World J Radiol. 2016;8(4):355369. DOI: 10.4329 /wir.v8.i4.355.

21. Tomford W.W. Transmission of disease through transplantation of musculoskeletal allografts. J Bone Joint Surg Am. 1995;77(11):1742-1754.

22. Hinsenkamp M., Muylle L., Eastlund T., Fehily D., Noël L., Strong D.M. Adverse reactions and events related to musculoskeletal allografts: reviewed by the World Health Organisation Project NOTIFY. Int Orthop. 2012;36(3):633-641. DOI: 10.1007/s00264-011-1391-7.

23. Grover V., Kapoor A., Malhotra R., Sachdeva S. Bone allografts: a review of safety and efficacy. Indian J Dent Res. 2011;22(3):496. DOI: 10.4103/0970-9290.87084.

24. Buck B.E., Malinin T.I., Brown M.D. Bone transplantation and human immunodeficiency virus. An estimate of risk of acquired immunodeficiency syndrome (AIDS). Clin Orthop Relat Res. 1989;(240):129-136.

25. Conrad E.U., Gretch D.R., Obermeyer K.R., Moogk M.S., Sayers M., Wilson J.J., Strong D.M. Transmission of the hepatitis- $C$ virus by tissue transplantation. J Bone Joint Surg Am. 1995;77(2):214-224.
26. O’Sullivan E.D., Battle R.K., Zahra S., Keating J.F., Marson L.P., Turner D.M. Allosensitization Following Bone Graft. Am J Transplant. 2017;17(8):2207-2211. DOI: 10.1111/ajt.14231.

27. Piaia M., Bub C.B., Succi G.M., Torres M., Costa T.H., Pinheiro F.C., Napimoga M.H. HLA-typing analysis following allogeneic bone grafting for sinus lifting. Cell Tissue Bank. 2017;18(1):75-81.

DOI: $10.1007 / \mathrm{s} 10561-016-9594-1$.

28. Mosconi G., Baraldi O., Fantinati C., Panicali L., Veronesi M., Cappuccilli M.L. et al. Donor-specific antiHLA antibodies after bone-graft transplantation. Impact on a subsequent renal transplantation: a case report. Transplant Proc. 2009;41(4):1138-1141. DOI: 10.1016/j.transproceed.2009.02.059.

29. Friedlaender G.E., Strong D.M., Sell K.W. Studies on the antigenicity of bone. II. Donor-specific anti-HLA antibodies in human recipients of freeze-dried allografts. J Bone Joint Surg Am. 1984;66(1):107-112.

30. Ward W.G., Gautreaux M.D., Lippert D.C. ${ }^{2 n d}$, Boles C. HLA sensitization and allograft bone graft incorporation. Clin Orthop Relat Res. 2008;466(8):1837-1848. DOI: $10.1007 / \mathrm{s} 11999-008-0294-4$.

31. Quattlebaum J.B., Mellonig J.T., Hensel N.F. Antigenicity of freeze-dried cortical bone allograft in human periodontal osseous defects. $J$ Periodontol. 1988;59(6):394-397.

32. Reikerås O., Reinholt F.P., Zinöcker S., Shegarfi H., Rolstad B. Healing of long-term frozen orthotopic bone allografts is not affected by MHC differences between donor and recipient. Clin Orthop Relat Res. 2011;469(5): 1479-1486. DOI: 10.1007/s11999-011-1796-z.

33. Fretwurst T., Spanou A., Nelson K., Wein M., Steinberg T., Stricker A. Comparisonof four different allogeneic bone grafts for alveolar ridge reconstruction: a preliminary histologic and biochemical analysis. Oral Surg Oral Med Oral Pathol Oral Radiol. 2014;118(4):424-431. DOI: 10.1016/j.oooo.2014.05.020.

34. Lorenz J., Schlee M., Al-Maawi S., Chia P., Sader R.A., Ghanaati S. Variant Purification of an Allogeneic Bone Block. Acta Stomatol Croat. 2017;51(2):141-147. DOI: $10.15644 /$ asc $51 / 2 / 7$.

35. Klemm K.W. Gentamicin-PMMA chains (Septopal chains) for the local antibiotic treatment of chronic osteomyelitis. Reconstr Surg Traumatol. 1988;20:11-35.

36. Alt V., Bitschnau A., Böhner F., Heerich K.E., Magesin E., Sewing A. et al. Effects of gentamicin and gentamicinRGD coatings on bone ingrowth and biocompatibility of cementless joint prostheses: An experimental study in rabbits. Acta Biomater. 2011;7(3):1274-1280. DOI: 10.1016/j.actbio.2010.11.012.

37. Heppert V., Wagner Ch., Glatzel U., Wentzensen A. Prinzipien der operative-chirurgischen Therapie der Osteitis. Trauma Berufskrankh. 2002:4(3):321-328. (in German).

38. Luther C., Unger K., Heppert V., Simon R., Hitzigrath C., Germann G., Sauerbier M. [Chronic osteitis of the lower extremities. An interdisciplinary treatment concept]. Unfallchirurg. 2010;113(5):386-393. (in German). DOI: $10.1007 / \mathrm{s} 00113-009-1709-8$. 


\section{INFORMATION ABOUT AUTHORS:}

Reinhard Schnettler - MD, Professor, the Head of the Trauma Surgery Department, University Medical Center Giessen and Marburg, Giessen, Germany

Jorg Franke - MD, the Head of the Department of Trauma and Orthopaedic Surgery, Elbe Klinikum Stade Unfallchirurgie und Orthopädie, Stade, Germany

Dmitry Rimashevskiy - Cand. Sci. (Med.) Associate Professor, Traumatology and Orthopedics Department, Peoples' Friendship University of Russia, Moscow, Russian Federation

Nikolai V. Zagorodniy - Dr. Sci. (Med.), Professor, the Head of Traumatology and Orthopedics Department, Peoples' Friendship University of Russia, Moscow, Russian Federation

Nurlan Batpenov - MD, Dr. Sci. (Med.), Professor, Director of Scientific Research Institute of Traumatology and Orthopedics, Astana, Kazakhstan, Astana, Kazakhstan

Ronald E. Unger - MD, Institute of Pathology, Johannes Gutenberg University, Mainz, Germany

Sabina Wenisch - MD, Professor, Institute of Veterinary Anatomy, Histology and Embryology, Justus Liebig University of Giessen, Giessen, Germany

Mike Barbeck - MD, Senior Researcher, Julius Wolff Institute and Center for Musculoskeletal Surgery, Charité - Universitätsmedizin Berlin; Botiss Biomaterials, Berlin, Germany

\section{ИНФОРМАЦИЯ ОБ АВТОРАХ:}

Рейнхард Шнеттлер - профессор, руководитель отделения травматологии и ортопедии, Университетский медицинский центр Гиссена, Гиссенский университет Юстуса фон Либиха, Гиссен, Германия

Иорг Франке - руководитель отделения ортопедической хирургии, Эльбе Клиника неотложной хирургии и ортопедии, Штаде, Германия

Денис Владимирович Римашевский - канд. мед. наук, доцент кафедры травматологии и ортопедии, Российский университет дружбы народов, Москва, Россия

Николай Васильевич Загородний - д-р мед. наук, профессор, заведующий кафедрой травматологии и ортопедии, Российский университет дружбы народов, Москва, Россия

Нурлан Джумагулович Батпенов - д-р мед. наук, профессор, директор Научно-исследовательского института травматологии и ортопедии, Астана, Республика Казахстан

Роланд Унгер - Институт патологии, Университет Джоанеса Гутенберга, Майнц, Германия

Сабина Вениш - профессор, Институт ветеринарной анатомии, гистологии и эмбринологии Гиссенского университета Юстуса фон Либиха, Гиссен, Германия

Майк Барбек - старший научный сотрудник, Институт Юлиуса Вульфа и Центр скелетно-мышечной хирургии Шарите - Медицинский университет Берлина; Ботис Биоматериалс, Берлин, Германия 